added a series of fine unpublished drawings from the North American and Brazilian expeditions of Maximilian, Prince of Wied. The papers include a comment on these by Dr. J. Röder and a biographical note on his ancestor by Karl Victor, Prince of Wied. The publication of these proceedings was considerably delayed, and the thirty-first Congress was held at São Paulo before they appeared. The thirtysecond Congress, to be held in Copenhagen, has been announced for August 1956.

\section{Geographical Association: Annual Conference}

THE annual conference of the Geographical Association will be held in the London School of Economics, Houghton Street, London, W.C.2, during January 3-6, 1956. The presidential address, by Mr. L. S. Suggate, will be on "Aspects of Geography Teaching in Schools". In addition to the usual lectures, sectional meetings, excursions, etc., a joint meeting with the Royal Geographical Society and the Institute of British Geographers will be held in the former's premises in Kensington Gore, London, S.W.7, at which "Some Medical Aspects of Geography" will be discussed. Further information can be obtained from the honorary conference organizer, R. C. Honeybone, University of London Institute of Education, Malet Street, London, W.C.2.

The spring conference of the Association will be held at Brighton during April 3-7, 1956, and the programme and reservation leaflet for this meeting will be issued with the January issue of the Association's journal, Geography.

\section{Cloud Physics: Conference in London}

A CONFERENCE on "Cloud Physics", arranged jointly by the Physical Society and the Royal Meteorological Society, will be held in the Department of Meteorology, Imperial College of Science and Technology, London, S.W.7, during January 4-5. After an introductory talk by B. J. Mason (Imperial College) on the scope of cloud physics, the first half-day will be devoted to the atmospheric aerosol, with papers by C. Junge and H. Weickmann (both of the United States) on, respectively, the nuclei of atmospheric condensation and the constitution of non-precipitating clouds. For the remaining day and a half the microphysics of clouds will be considered, with papers by the following: B. J. Mason, R. Braham (United States), F. E. Ludlam (Imperial College), J. S. Marshall (Canada) and J. T. Wormell (Cambridge). The merting will be open to non-members. Application forms, to be returned by December 15, can be obtained from Miss E. Miles, Physical Society, 1 Lowther Gardens, London, S.W.7.

\section{The Queen's University of Belfast}

THE following have been appointed to lectureships in The Queen's University of Belfast : Dr. R. J. Magee (inorganic chemistry), Dr. M. F. Grundon (organic chemistry), J. M. Gilchrist and Dr. W. F. K. Kerr (mechanical engineering), J. M. W. MeBride (light electrical engineering), and Dr. D. S. McIlhagger (electrical engineering). The University has received the following grants : to the Department of Applied Mathematics, $£ 2,250$ from H.M. Treasury for a rocket research project with which the Department of Physics will be associated, and $£ 1,200$ in connexion with the International Geophysical Year; to the Department of Organic Chemistry, $£ 500$ a year from the Medical Research Council for work on branched- chain carbohydrates, and $£ 450$ a year from the British Empire Cancer Campaign for work on the synthesis of colchicine.

\section{Announcements}

Sir Haroto Roxber Cox will deliver the twentieth Parsons Memorial Lecture at the Institution of Civil Engineers on December 13; he will speak on "The Development of the Gas Turbine".

DR. E. J. BouRne, reader in organic chemistry in the University of Birmingham, has been appointed to the University of London chair of chemistry tenable at the Royal Holloway College in succession to the late Prof. Gwyn Williams.

THE Massachusetts Institute of Technology has appointed Dr. R. R. Doell and Dr. J. W. Winchester to be assistant professors in the Department of Geology and Geophysics. Their subjects are seismology and geomagnetism, and nuclear geochemistry, respectively.

THE Meldola Medal, which is the gift of the Society of Maccabæans, is being offered for award early in 1956 to the chemist who, being a British subject and less than thirty years old on December 31, 1955, shows the most promise, as indicated by published chemical work brought to the notice of the Council of the Royal Institute of Chemistry before December 31. Communications should be addressed to the President, Royal Institute of Chemistry, 30 Russell Square, London, W.C.1, the envelope being marked "Meldola Medal".

Sir George Beildi Memorial awards, which are considered at intervals by administrators representing the Royal Institute of Chemistry, the Society of Chemical Industry and the Institute of Metals, are made to British scientific research workers, preference being given to investigations relating to the special interests of Sir George Beilby, including fuel economy, chemical engineering and metallurgy. In general, the awards are given to younger workers for original investigations over a number of years. For awards early in 1956, the attention of the administrators should be directed, before December 31, to outstanding work of the nature indicated, all communications being addressed to the Convener of the Administrators, Sir George Beilby Memorial Fund, Royal Institute of Chemistry, 30 Russell Square, London, W.C.I.

A sUMmer school on the applications of spectro. scopy to chemical problems and on intermolecular forces and the properties of fluids will be held in the Department of Physical Chemistry, University of Cambridge, during August 18-25, 1956. Among the lecturers will be Prof. R. G. W. Norrish, Mr. R. P. Bell and Prof. H. C. Longuet-Higgins. Full opportunity will be provided for discussions. Further information can be obtained from the Secretary of the Summer School, Department of Physical Chemistry, Free School Lane, Cambridge.

THE Manchester and District Section of the Royal Institute of Chemistry is organizing an exhibition of laboratory apparatus and techniques with particular reference to instrumentation, to be held in the Manchester College of Technology on January 4 (2-8 p.m.) and January 5 (10 a.m. -8 p.m.). Some thirty-five exhibitors are taking part, and there will be various demonstrations (for example, glass-blowing and vapour-phase chromatography). 